\title{
Exploring E-learning Challenges During the Global COVID-19 Pandemic: A Review
}

\author{
Qurotul Aini \\ Faculty of Science and Technology, \\ Universitas Raharja \\ Tangerang, Banten, 15117, Indonesia \\ aini@raharja.info \\ Panca O. Hadi Putra* \\ Faculty of Science and Technology, \\ Universitas Raharja \\ Tangerang, Banten, 15117, Indonesia \\ panca@ raharja.info
}

\author{
Mukti Budiarto \\ Faculty of Science and Technology, \\ Universitas Raharja \\ Tangerang, Banten, 15117, Indonesia \\ mukti@ raharja.info \\ Untung Rahardja \\ Faculty of Science and Technology, \\ Universitas Raharja \\ Tangerang, Banten, 15117, Indonesia \\ untung@raharja.info
}

\begin{abstract}
The world is currently battling the coronavirus disease 2019 (COVID-19) that has been declared as a global pandemic since mid-March 2020. The pandemic has inevitably impacted social and economic activities of the nation, including those in the education sector. As the governments have mandated universities to close their campuses, learning activities has been forced to move online. In this difficult situation, many university administrators, lecturers, as well as students may find it difficult to adapt to the so-called "new normal" ways of learning.

Hence, as this is an unprecedented situation, this study explores the challenges faced by universities as academic institutions, lecturers, and students. This study starts by conducting a literature review concerning the challenges in e-learning in context of a pandemic. Data

collected are then analyzed qualitatively using inductive thematic analysis technique, resulting in a taxonomy of e-learning challenges during a pandemic. Our analysis shows that students are challenged by connectivity, e-learning system support, and technological and self-regulation issues. On the other hand, lecturers are being challenged by competency, operational, self-regulation, and isolation issues. Meanwhile, institutions identify financial support and change management as challenging issues. This study highlights the need for further investigation to address the aforementioned challenges in e-learning.
\end{abstract}

Keywords: E-learning, challenges, pandemic, COVID-19

\section{Introduction}

The coronavirus disease 2019, known as the COVID-19, was discovered in December 2019 (C. Huang et al. 2020) and declared as a pandemic in mid-March 2020 as the virus spread rapidly across the world (Sohrabi et al. 2020). The repercussions of such rapid spread force organizations of all types to shift their operations to online mode. Higher education institutions such as universities are no exception to this unprecedented situation. Many governments have mandated learning to be conducted exclusively online in lieu of face-to-face on-campus learning. However, it is also noted that such closure would

* Corresponding author 
have negative impact on students' learning (R. Huang et al. 2020), which may be addressed by delivering education online via the Internet through e-learning system.

E-learning systems such as in a form of learning management system (LMS) provide a learning platform that can facilitate interactive learning at anytime and anywhere as long as their users are connected to the system via the Internet. A well-designed e-learning system typically does not only provide learning materials, but also facilitate other activities such quizzes, written examinations, and discussion forum. It is common to suggest that properly designed e-learning materials may prove an efficient and effective alternative to materials that are delivered offline. As e-learning plays an increasingly critical role during the pandemic, the heavy reliant on the use of e-learning also becomes a challenge, not only for higher education institutions, but also students and lecturers.

Successful implementation of e-learning systems hinges upon addressing the challenges faced by the users. Examining the challenges in e-learning may guide various stakeholders such as higher education institutions and policy makers to fulfil the needs of e-learning system users i.e. students and lecturers in order to effectively implement e-learning. While there have been many studies have attempted to uncover challenges that hamper e-learning implementation in general (Aung and Khaing 2015; Selim 2007; Tarus et al. 2015), there have been limited studies that focus on exploring the challenges of delivering e-learning in the context of the pandemic. Given the importance of continuous learning in this difficult time, this study seeks to explore the challenges being faced by students, lecturer, higher education institutions during the COVID-19 pandemic.

\section{Literature review}

This section reviews the literature related to e-learning usage and subsequent challenges in implementing it. The success of an information systems is dependent upon acceptance of its users (Almaiah et al. 2020). There have been numerous studies on the literature of user acceptance of elearning. Lack of consideration for factors that influence user acceptance of e-learning may prove to be challenges in e-learning. A study by Selim (2007) specify critical success factors (CSFs) for e-learning in higher education institutions. The CSFs are grouped into four categories, namely lecturers, students, information technology, and institution support. For lecturers, CFS include IT competency and attitude whereas in terms of information technology, CSFs include reliable infrastructure. For students, CSFs include time management and discipline, while for higher education institutions CSFs include technical support.

Another stream of literature that explores challenges in e-learning are in context of its implementation in specific cases. For instance, Tarus et al. (2015) explores challenges in implementing e-learning in Kenyan public universities. Involving lecturers and university staff as respondents, the Kenyan study reveals eight challenges, including inadequate ICT and e-learning infrastructure, financial constraints, lack of technical skills on e-learning development and extensive time required to develop materials, and lack of interest and commitment to use e-learning. The findings imply that these challenges must be addressed in order to successfully implement e-learning system.

Some of these challenges are in line with a review of studies on challenges in implementing e-learning in developing countries by Aung and Khaing (2015). This review of e-learning implementation in universities note that challenges include, inter alia, ICT infrastructure, lecturer's competencies, technical skills, ICT literacy, and awareness of e-learning benefits. Focused on the perspective of lecturers of in higher education institutions, Islam et al. (2015) identify five groups of challenges. These challenges include learning styles and culture, pedagogical e-learning, technical training, technology, and time management challenges. All in all, the literatures on challenges or factors that hinder implementation of e-learning boil down to three perspectives of e-learning stakeholders, namely students, lecturers, and higher education institutions. This informs our approach in reviewing the elearning challenges in the context of pandemic from these three perspectives, which we delineate in the following section. 


\section{Methodology}

This study is driven by a review question: "What are the challenges being faced in e-learning during the COVID-19 pandemic?" In order to answer this question and understand the challenges, we searched the extant academic literature as the source of data (see Figure 1). We queried the Scopus database in the end of August 2020. Scopus database was chosen as it indexes a wide selection of publications in multiple disciplines including other popular scholarly databases. The query string used for the search was "e-learning" AND "pandemic" AND "challenge". This query formulation is guided by the aforementioned review question. The query was entered into Scopus document search to yield articles for review. The search results are then refined by limiting publication date to year of 2020, which is the year of the beginning of the COVID-19 pandemic, resulting in 60 articles. In addition, the results were further limited by studies in that are in the final stage of publication, resulting in 49 articles. As inclusion criteria, articles should discuss e-learning in the context of pandemic. As exclusion criteria, articles that are not written in English and are of commentary or review type are not included. By applying these criteria, the results narrow down 16 articles. Furthermore, the full texts of these papers were then read to exclude those that focused solely on either e-learning, challenges, or pandemic. This results in final list containing seven articles. The full text of resulting articles obtained were managed using Mendeley reference management software and then re-read to extract challenges in e-learning. These challenges were then categorized inductively by coding based emerging themes using Atlas.ti and visualized using XMind. The emerging themes were then further grouped by categorizing them into three perspectives in e-learning, namely students, lecturers, and institutions, a similar categorization employed by Rasheed et al. (2020).

\section{Results \& Discussion}

This section discusses the results of the review, specifically challenges in e-learning in the context of a pandemic. The discussion of these challenges is grouped into separate sub-sections in accordance to three main perspectives in the use of e-learning, namely students, lecturers and higher education institutions. These challenges for students, lecturers, and higher education institutions are also summarized in Table 1, Table 2, and Table 3 respectively. In addition, the identified challenges are also presented visually as a taxonomy as seen in Figure 2.

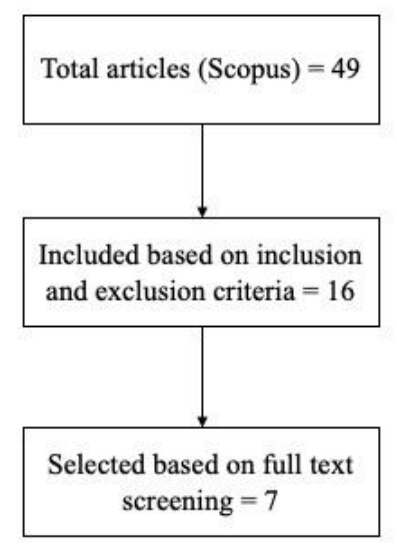

Figure 1. An overview of literature search results

\section{Student's challenges}

As e-learning necessitates students to study independently, they often find themselves challenged by self-regulation issues such as low motivation to study and ineffective communication with their fellow students (Rannastu-Avalos and Siiman 2020; Wan Hassan et al. 2020; Zhang et al. 2020). This selfregulation issue may be compounded should the students do not have adequate information and 
communications technology (ICT) knowledge (Wan Hassan et al. 2020). Learning virtually poses as a challenge for students since they may find it difficult sense cognitive, social, teaching presences in elearning systems (Rannastu-Avalos and Siiman 2020; Zulkefli et al. 2020). This is related to how well an e-learning system support those presences through use of appropriate features. In terms of e-learning system support, there are also other challenges with regard to overall user experience of the system. These include not only ease of use and usability aspects of the e-learning system, but also perceived availability of technical support and how well the system supports devices or equipment used by students (Almaiah et al. 2020; Wan Hassan et al. 2020; Zulkefli et al. 2020). In higher education institutions where there is not a standard system for delivering online learning, students may find themselves using various education platforms for different courses. This may also be a challenge for students (Al-Balas et al. 2020). Finally, as e-learning systems usually runs on the Internet, poor internet coverage or limited Internet data packages are also typical obstacles felt by e-learning students, especially those that come from developing countries with limited Internet connectivity and low bandwidth (Al-Balas et al. 2020; Farooq et al. 2020; Wan Hassan et al. 2020).

\section{Lecturer's challenges}

The pandemic comes a surprise to lecturer who find their way of teaching or general operations disrupted by the new way of learning. For lecturers who are not accustomed and trained to creating and delivering teaching materials for online platform, this may be a significant challenge (Farooq et al. 2020). Formal training in creating and delivering materials may be necessary for lecturers in conducting e-learning as it incorporates both instructional and visual design for the course materials to be effective. Operationally, lecturers find themselves spend more time preparing for e-learning compared to offline learning, thus higher workload with increasing volumes of learning materials (Rannastu-Avalos and Siiman 2020). As mode of delivery is entirely online, observing and maintaining students' engagement in both asynchronous and synchronous settings may also be difficult for lecturers (Farooq et al. 2020; Rannastu-Avalos and Siiman 2020). This situation may affect to assessment components being delivered e-learning system (Rannastu-Avalos and Siiman 2020).

\section{Institution's challenges}

In these trying times, higher education institutions must ensure that they sufficiently support e-learning usage, not only technically as required by students as discussed previously, but also financially. Financial support may come in a form of budgetary provision and ensuring that e-learning implementation project is not delayed (Almaiah et al. 2020). Such support may be foundational for an implementation of e-learning to be a success. Once the e-learning has been implemented, higher education institutions may also face a problem of a lack of adoption, which may stem from change management issues, such as lack of awareness and interests among users (Almaiah et al. 2020). In this pandemic, the issue of resistance to change is still an issue from the perspective of higher education institutions as the current situation forces learning and teaching activities to shift mode (Almaiah et al. 2020). Hence, educational institutions are encouraged to be able to leverage their knowledge of needs and challenges of students and lecturer in order to provide reliable e-learning system. While many studies have focused on the challenges faced by students and lecturers, as our review shows, there are limited studies documenting challenges faced by higher education institutions. When discussing these challenges for higher education institutions, lecturers, and students as distinct groups, it may seem that these challenges may be exclusive to each group. However, we find that these challenges are interrelated and may influence each other, such as those self-regulation issues for both students and lecturers we discuss in previous sub-section or how lack of training for lecturers may influence their ability to maintain students' engagement online. Therefore, there may be necessary to further examine of how these challenges are related and influence each other in order to implement e-learning successfully in the context of a pandemic. 
Table 1. Previous studies on student's e-learning challenges during pandemic

\begin{tabular}{|c|c|c|c|}
\hline $\begin{array}{l}\text { Inductive } \\
\text { challenge } \\
\text { categories }\end{array}$ & $\begin{array}{l}\text { Inductive challenge } \\
\text { sub-categories }\end{array}$ & Challenges & Literature \\
\hline \multirow[t]{13}{*}{ Students } & \multirow[t]{2}{*}{$\begin{array}{l}\text { Infrastructure \& } \\
\text { Connectivity } \\
\text { challenges }\end{array}$} & $\begin{array}{l}\text { Poor internet } \\
\text { coverage/infrastructure }\end{array}$ & $\begin{array}{l}\text { (Al-Balas et al. } \\
\text { 2020; Farooq et al. } \\
\text { 2020) }\end{array}$ \\
\hline & & $\begin{array}{l}\text { Limitation in internet data } \\
\text { packages/ Internet connectivity } \\
\text { and low bandwidth }\end{array}$ & $\begin{array}{l}\text { (Al-Balas et al. } \\
\text { 2020; Farooq et al. } \\
\text { 2020; Wan Hassan et } \\
\text { al. 2020) }\end{array}$ \\
\hline & \multirow[t]{8}{*}{$\begin{array}{l}\text { E-learning system } \\
\text { support challenges }\end{array}$} & $\begin{array}{l}\text { Lacking in suitable } \\
\text { devices/technical equipment }\end{array}$ & $\begin{array}{l}\text { (Al-Balas et al. } \\
\text { 2020; Zulkefli et al. } \\
\text { 2020) }\end{array}$ \\
\hline & & Variation of education platforms & $\begin{array}{l}\text { (Al-Balas et al. } \\
\text { 2020) }\end{array}$ \\
\hline & & Ease of use & $\begin{array}{l}\text { (Almaiah et al. 2020; } \\
\text { Wan Hassan et al. } \\
\text { 2020; Zulkefli et al. } \\
\text { 2020) }\end{array}$ \\
\hline & & $\begin{array}{l}\text { Technical support/help } \\
\text { availability }\end{array}$ & $\begin{array}{l}\text { (Almaiah et al. 2020; } \\
\text { Wan Hassan et al. } \\
\text { 2020; Zulkefli et al. } \\
\text { 2020) }\end{array}$ \\
\hline & & Accessibility & $\begin{array}{l}\text { (Almaiah et al. 2020; } \\
\text { Wan Hassan et al. } \\
\text { 2020; Zulkefli et al. } \\
\text { 2020) }\end{array}$ \\
\hline & & Social presence & (Zulkefli et al. 2020) \\
\hline & & Teaching presence & (Zulkefli et al. 2020) \\
\hline & & Cognitive presence & $\begin{array}{l}\text { (Rannastu-Avalos } \\
\text { and Siiman 2020; } \\
\text { Zulkefli et al. 2020) }\end{array}$ \\
\hline & \multirow{3}{*}{$\begin{array}{l}\text { Technological } \\
\text { competency and self- } \\
\text { regulation challenges }\end{array}$} & Lack of ICT knowledge & $\begin{array}{l}\text { (Wan Hassan et al. } \\
\text { 2020) }\end{array}$ \\
\hline & & Low motivation & $\begin{array}{l}\text { (Rannastu-Avalos } \\
\text { and Siiman 2020; } \\
\text { Wan Hassan et al. } \\
\text { 2020) }\end{array}$ \\
\hline & & $\begin{array}{l}\text { Maintaining effective } \\
\text { communication with peers }\end{array}$ & (Zhang et al. 2020) \\
\hline
\end{tabular}


Table 2. Previous studies on lecturer's e-learning challenges during pandemic

\begin{tabular}{|c|c|c|c|}
\hline $\begin{array}{l}\text { Inductive } \\
\text { challenge } \\
\text { categories }\end{array}$ & $\begin{array}{l}\text { Inductive challenge } \\
\text { sub-categories }\end{array}$ & Challenges & Literature \\
\hline \multirow[t]{11}{*}{ Lecturers } & \multirow[t]{6}{*}{$\begin{array}{l}\text { Competency \& } \\
\text { operational challenges }\end{array}$} & Lack of proper/formal training & $\begin{array}{l}\text { (Farooq et al. } \\
\text { 2020) }\end{array}$ \\
\hline & & $\begin{array}{l}\text { Maintaining online learner's } \\
\text { engagement/ Involving student } \\
\text { is challenging }\end{array}$ & $\begin{array}{l}\text { (Farooq et al. 2020; } \\
\text { Rannastu-Avalos } \\
\text { and Siiman 2020) }\end{array}$ \\
\hline & & Higher workload & $\begin{array}{l}\text { (Rannastu-Avalos } \\
\text { and Siiman 2020) }\end{array}$ \\
\hline & & $\begin{array}{l}\text { Difficult to observe all } \\
\text { students }\end{array}$ & $\begin{array}{l}\text { (Rannastu-Avalos } \\
\text { and Siiman 2020) }\end{array}$ \\
\hline & & Assessment issues & $\begin{array}{l}\text { (Rannastu-Avalos } \\
\text { and Siiman 2020) }\end{array}$ \\
\hline & & $\begin{array}{l}\text { Lessons more concentrated in } \\
\text { volume }\end{array}$ & $\begin{array}{l}\text { (Rannastu-Avalos } \\
\text { and Siiman 2020) }\end{array}$ \\
\hline & \multirow[t]{3}{*}{$\begin{array}{l}\text { Lecturer's self- } \\
\text { regulation challenges }\end{array}$} & Learning difficulties & $\begin{array}{l}\text { (Rannastu-Avalos } \\
\text { and Siiman 2020) }\end{array}$ \\
\hline & & $\begin{array}{l}\text { Lack of time management } \\
\text { skills }\end{array}$ & $\begin{array}{l}\text { (Rannastu-Avalos } \\
\text { and Siiman 2020) }\end{array}$ \\
\hline & & Low motivation & $\begin{array}{l}\text { (Rannastu-Avalos } \\
\text { and Siiman 2020) }\end{array}$ \\
\hline & \multirow[t]{2}{*}{$\begin{array}{l}\text { Lecturer's isolation } \\
\text { challenges }\end{array}$} & $\begin{array}{l}\text { Working from home and } \\
\text { maintaining work-life balance }\end{array}$ & $\begin{array}{l}\text { (Farooq et al. } \\
\text { 2020) }\end{array}$ \\
\hline & & $\begin{array}{l}\text { Feeling of loneliness in a } \\
\text { video lesson }\end{array}$ & $\begin{array}{l}\text { (Rannastu-Avalos } \\
\text { and Siiman 2020) }\end{array}$ \\
\hline
\end{tabular}

Table 3. Previous studies on institution's e-learning challenges during pandemic

\begin{tabular}{|l|l|l|l|}
\hline $\begin{array}{l}\text { Inductive } \\
\text { challenge } \\
\text { categories }\end{array}$ & $\begin{array}{l}\text { Inductive challenge } \\
\text { sub-categories }\end{array}$ & Challenges & Literature \\
\hline \multirow{2}{*}{ Institution } & $\begin{array}{l}\text { Financial support } \\
\text { challenges }\end{array}$ & Lack of financial support & $\begin{array}{l}\text { (Almaiah et al. } \\
2020)\end{array}$ \\
\cline { 3 - 4 } & Projects delay & $\begin{array}{l}\text { (Almaiah et al. } \\
2020)\end{array}$ \\
\cline { 2 - 4 } & \multirow{2}{*}{$\begin{array}{l}\text { Change management } \\
\text { challenges }\end{array}$} & Lack of awareness & $\begin{array}{l}\text { (Almaiah et al. } \\
2020)\end{array}$ \\
\cline { 3 - 4 } & & Lack of interests & $\begin{array}{l}\text { (Almaiah et al. } \\
2020)\end{array}$ \\
\cline { 3 - 4 } & & Resistance to change & $\begin{array}{l}\text { (Almaiah et al. } \\
2020)\end{array}$ \\
\hline
\end{tabular}




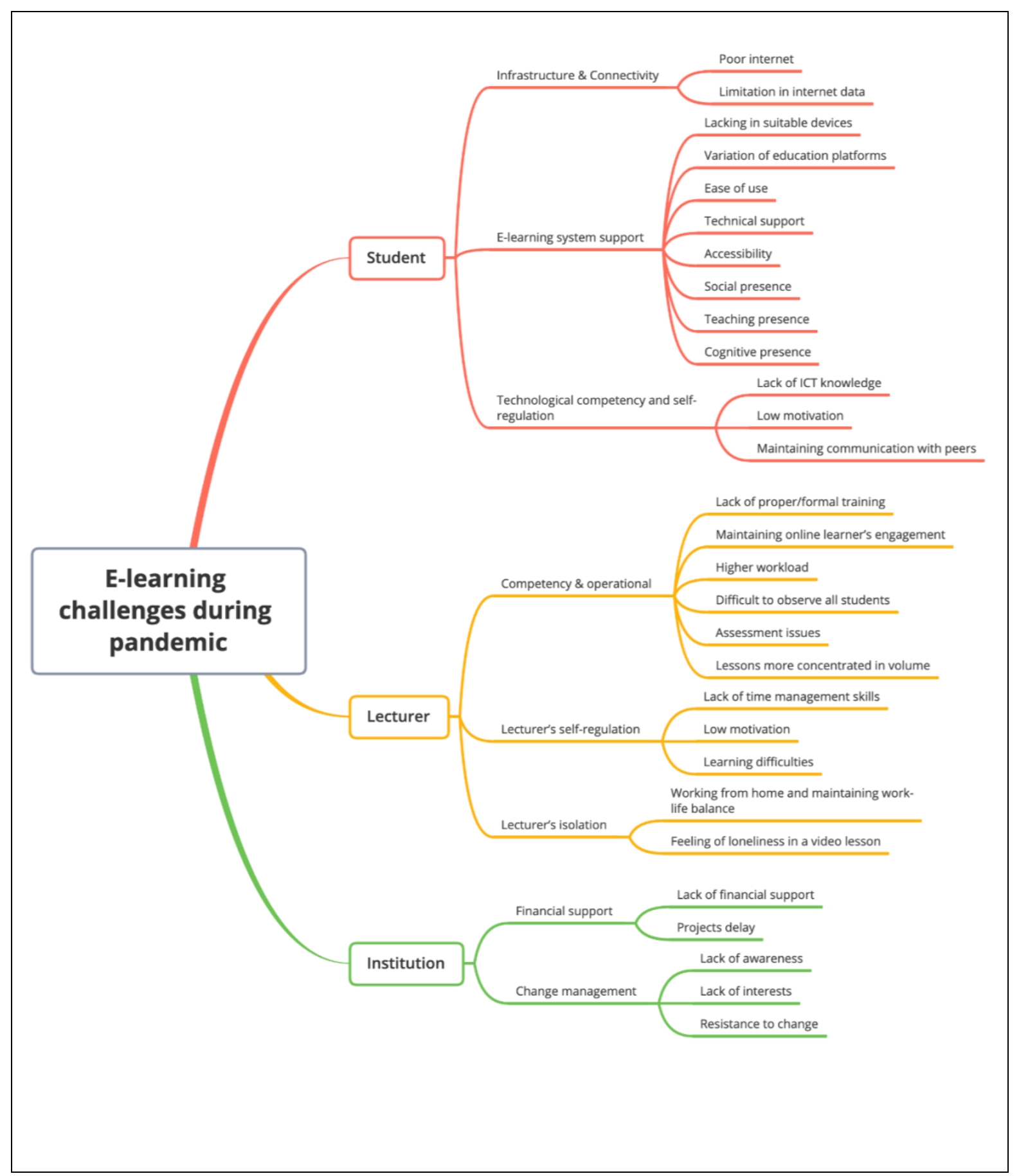

Figure 2. Taxonomy of challenges in e-learning during COVID-19 pandemic

\section{Conclusion}

This study presents a review exploring the challenges in e-learning during the global COVID-19 pandemic from the points of view lecturers, students, and academic institutions. Having examined 49 studies including the resulting seven studies from the Scopus databased in between January to August 2020, we identify and categorize challenges inductively into themes and grouped into the said points of view. We understand that students are being challenged not by the typical technological and selfregulation issues such as lack of ICT knowledge and low motivation, but also Internet connectivity and e-learning support issues. We also understand that some of the challenges faced by students are shared by lecturers especially those of self-regulation issues. Additionally, lecturers are hampered by competency and operational issues in delivering e-learning materials, such as lack of training, 
maintaining student's engagement, and higher teaching workload. Furthermore, isolation issues such as loneliness in video lesson and maintaining work-life balance in a working from home setting are also concerns of lecturers. Finally, the global pandemic also brings about a range institutional challenges such as obtaining financial support and addressing the change management issues e.g. resistance to change and lack of interests in adopting e-learning. This study is limited by selection criteria it employed and scholarly database chosen. If we had accessed other databases such as Google Scholar with varied additional queries such as "online learning", we may have gotten more articles. However, this study may be adequate in conveying e-learning challenges during a pandemic as a reference for future research.

\section{References}

Al-Balas, M., Al-Balas, H. I., Jaber, H. M., Obeidat, K., Al-Balas, H., Aborajooh, E. A., Al-Taher, R., and Al-Balas, B. 2020. "Distance Learning in Clinical Medical Education amid COVID-19 Pandemic in Jordan: Current Situation, Challenges, and Perspectiv

Almaiah, M. A., Al-Khasawneh, A., and Althunibat, A. 2020. "Exploring the Critical Challenges and Factors Influencing the E-Learning System Usage during COVID-19 Pandemic," Education and Information Technologies, Springer.

Aung, T. N., and Khaing, S. S. 2015. "Challenges of Implementing E-Learning in Developing Countries: A Review," in International Conference on Genetic and Evolutionary Computing, Springer, pp. 405-411.

Farooq, F., Rathore, F. A., and Mansoor, S. N. 2020. "Challenges of Online Medical Education in Pakistan during COVID-19 Pandemic," Journal of the College of Physicians and Surgeons Pakistan (30:1), pp. S67-S69. (https://doi.org/10.29271/jcpsp.2020.Supp1.

Huang, C., Wang, Y., Li, X., Ren, L., Zhao, J., Hu, Y., Zhang, L., Fan, G., Xu, J., and Gu, X. 2020. "Clinical Features of Patients Infected with 2019 Novel Coronavirus in Wuhan, China," The Lancet (395:10223), Elsevier, pp. 497-506.

Huang, R., Tlili, A., Chang, T.-W., Zhang, X., Nascimbeni, F., and Burgos, D. 2020. "Disrupted Classes, Undisrupted Learning during COVID-19 Outbreak in China: Application of Open Educational Practices and Resources," Smart Learning Environments (7:1), Sp

Islam, N., Beer, M., and Slack, F. 2015. "E-Learning Challenges Faced by Academics in Higher Education," Journal of Education and Training Studies (3:5), Redfame, pp. 102-112.

Rannastu-Avalos, M., and Siiman, L. A. 2020. "Challenges for Distance Learning and Online Collaboration in the Time of Covid-19: Interviews with Science Teachers," Lecture Notes in Computer Science (Including Subseries Lecture Notes in Artificial Intelligence and Lecture Notes in Bioinformatics), pp. 128-142. (https://doi.org/10.1007/978-3-030-58157-2_9).

Rasheed, R. A., Kamsin, A., and Abdullah, N. A. 2020. "Challenges in the Online Component of Blended Learning: A Systematic Review," Computers \& Education (144), p. 103701. (https://doi.org/10.1016/j.compedu.2019.103701).

Selim, H. M. 2007. "Critical Success Factors for E-Learning Acceptance: Confirmatory Factor Models," Computers \& Education (49:2), pp. 396-413. (https://doi.org/10.1016/j.compedu.2005.09.004).

Sohrabi, C., Alsafi, Z., O’Neill, N., Khan, M., Kerwan, A., Al-Jabir, A., Iosifidis, C., and Agha, R. 2020. "World Health Organization Declares Global Emergency: A Review of the 2019 Novel Coronavirus (COVID-19)," International Journal of Surgery, Elsevier

Tarus, J. K., Gichoya, D., and Muumbo, A. 2015. "Challenges of Implementing E-Learning in Kenya: A Case of Kenyan Public Universities," International Review of Research in Open and Distributed Learning (16:1), Athabasca University Press (AU Press), pp. 12

Wan Hassan, W. A. S., Ariffin, A., Ahmad, F., Sharberi, S. N. M., Nor Azizi, M. I., and Zulkiflee, S. N. 2020. "Covid-19 Pandemic: Langkawi Vocational College Student Challenge in Using Google Classroom for Teaching and Learning (T\&amp;L)," International

Zhang, R., Mestre, P., Serodio, C., Prada, M., and Gao, W. 2020. "Web-Based Teamwork: Distributed Software Development Course under Covid-19," in 2020 15th International Conference on Computer Science \& Education (ICCSE), pp. 45-50. (https://doi.org/10.1109/ICCSE49874.2020.9201661). 
Zulkefli, N. A. M., Hashim, H., and Syahrin, S. 2020. "Evaluating E-Learning Google Classroom Tools for Computer Science Subjects during Covid-19 Pandemic," International Journal of Advanced Trends in Computer Science and Engineering (9:4), pp. 6251-6258. (https://doi.org/10.30534/ijatcse/2020/304942020). 